\title{
The influence of the cooling method on shortening the cycle of multi-layer arc-surfacing of thin walls
}

Keywords:

multi-layer arc hardfacing; thin wall; 3D printing

\begin{abstract}
The use of 3D printing methods in the industry is becoming more frequent and popular. It brings specific economic effects, enables quick and precise production of machine parts and devices. The article presents a fragment of research carried out in the Welding Engineering Department of the Warsaw University of Technology on the application of MAG arc welding for 3D printing. The MAG method was used to try to produce thin walls. The aim of the presented research was to determine the effect of the cooling method on shortening the time of manufacturing the 3D model of thin walls. The models were made using G3Si1 and 316 LSi electrode wires. In the first part of the research, an interpass temperature of $50{ }^{\circ} \mathrm{C}, 100^{\circ} \mathrm{C}$ and $150^{\circ} \mathrm{C}$, achieved by free cooling was adopted. In the second part, the interpass temperature was $100^{\circ} \mathrm{C}$ and was achieved by forced cooling with a copper plate, a fan and a stream of compressed air. The greatest reduction in the time of manufacturing the 3D model of a thin wall was obtained for cooling using compressed air.
\end{abstract}

\section{Introduction}

3D Printing includes a collection of Rapid Modelling methods, Rapid Prototyping, Rapid Manufacturing and Rapid Tooling [1]. It allows you to create 3D objects of any geometry, starting with their models, through fully functional prototypes, and ending with tools or short production runs. It enables the design and manufacture of difficult elements, sometimes even impossible to do with traditional techniques, without the need of using technological equipment and tools specific to these techniques.

Among numerous methods of 3D forming, there are techniques using welding heat sources [2]. One of the first was a beam of laser light $[3,4]$. Thanks to the selective melting of powders, it is possible to manufacture elements from such materials as cobalt, titanium alloys, aluminum and stainless steel. Research is also being conducted on the use of a welding arc.

In the work carried out in the Welding Engineering Department of the Warsaw University of Technology, arc welding is applied with a consumable electrode in the shielding of MIG/

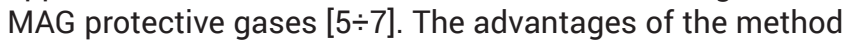
include a wide range of surfaced materials, high efficiency, the ability to robotize the process and its easy control, the availability of equipment and a relatively low cost. The experience and practice in using the MIG/MAG method for surface modification as well as in the regeneration and repair of machine parts is also important. The potential of the MIG/ MAG method also raises due to a number of its functional varieties, including low-energy ones. Limiting the amount of heat introduced to the padding weld, and thus reducing its deformations, allows to maintain the correct geometry of complex 3D models. An interesting example is the CMT (Cold Metal Transfer) variety, developed in 2004 by Fronius [8]. It is characterized by high stability, reduction of splash and repeatability of the obtained effect.

\section{Subject and methodology of the research}

3D printing of thin-walled objects based on MIG/MAG arc surfacing involves introducing excessive heat to the model. Even with the use of the low-energy CMT variant, a progressive deformation of the walls is observed. It was necessary

dr inż. Paweł Cegielski, dr inż. Jarosław Grześ, inż. Wojciech Łacisz - Warsaw University of Technology

Corresponding author. pcegiels@wip.pw.edu.pl 
to use breaks between groups of layers (padding welds),

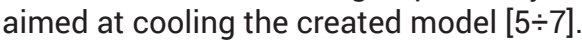

As a part of the conducted research, the influence of selected methods of interlayer cooling of 3D metal models on the time of their production by arc welding was analyzed. The goal was to determine the possibility of speeding up the process.

The 3D model tested was a thin metal wall obtained by successively surfaced layers - padding welds. The detailed scope of work included [9]:

- development of assumptions and research methodology,

- construction and configuration of the measurement stand,

- development of a robot control software,

- selection of basic and additional materials as well as welding parameters,

- analysis of cooling methods,

- developing a procedure for making thin walls,

- performing a surfacing trial,

- analysis of the results.

The tested wall models were created by MAG arc welding in a low-energy CMT variant. The tests were carried out on a robotic station (Fig. 1), the basic equipment of which was:

- modernized IRp-6 welding robot,

- single-axis rotary positioner,

- TPS 2700 CMT power source with ROB 3000 interface,

- temperature measurement system.

The temperature was controlled and measured using (Table I):

- Abatronic AB-8855 pyrometer with computer recording (sampling frequency approx. $2 \mathrm{~Hz}$ ),

- Metex M-4660A multimeter with a K-type thermocouple connected to the IRp- 6 robot monitoring system and real-time recording during the surfacing process (sampling frequency of approx. $2 \mathrm{~Hz}$ ).

To create the 3D models of the metal thin wall, two additional materials were selected, differing significantly in their properties. The first one is the electrode wire for the welding of G3Si1 structural steels, characterized by a ferritic-perlitic structure. The second one is 316LSi electrode wire with austenitic structure. The chemical composition and basic strength properties based on the manufacturer (ESAB) are shown in Table II.

The S235 and 304 steel plates with the dimensions of $150 \times 50 \times 4 \mathrm{~mm}$ and $150 \times 50 \times 2.5 \mathrm{~mm}$ were used as the base plates on which particular layers of 3D models were surfaced. The following mixtures were used as a shielding

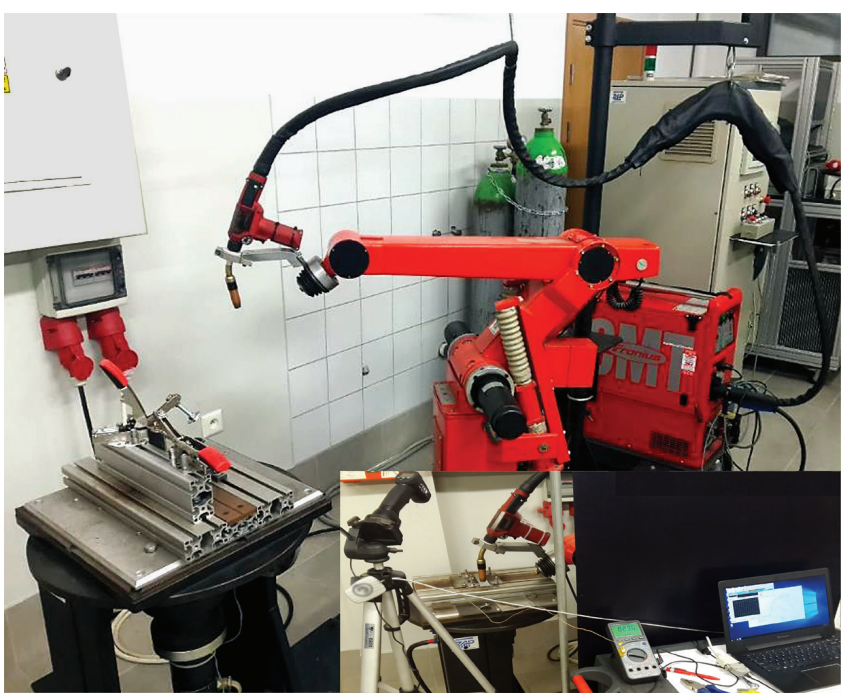

Fig. 1. Test stand

gas: $80 \% \mathrm{Ar}+20 \% \mathrm{CO}_{2}$ (M21 according to PN-EN ISO 14175) for the 3D-G3Si1 model, and $98 \% \mathrm{Ar}+2 \% \mathrm{O}_{2}$ (M13 according to PN-EN ISO 14175) for the 3D-316LSi model.

In order to ensure high repeatability of tests, the ignition and extinguishing of the arc took place from the level of the welding robot control program. A welding system built into the welding source to start and finish the welding process made it possible to set the experimentally selected values and duration of the initial and final current as well as the transition time between these values and the target surfacing current (Table III).

The developed control software was designed to integrate the work of the welding robot, the power source and temperature measurement using a thermocouple. The procedures of ignition and extinguishing of the arc, calibration of the burner position, setting movements, working motions and temperature measurement procedure have also been implemented in it.

Process parameters were determined based on preliminary tests. They were selected to ensure the correct and repeatable geometry of the thin wall 3D model. A higher initial current and an appropriate transition time to the target value have been programmed in the welding source. Parameters are presented in Table III. After applying each layer, the time of the final blow by the shielding gas was extended to 3 seconds.

Table I. Parameters of temperature measuring devices

\begin{tabular}{|c|c|c|c|c|}
\hline Device & Model & Range of measurement & Accuracy of measurement & Resolution (sensitivity) \\
\hline Pyrometer & Abatronic AB-8855 & $-50 \div 1050^{\circ} \mathrm{C}$ & $\begin{array}{c}-50 \div 200^{\circ} \mathrm{C} / \pm 1,5 \% \\
200 \div 538{ }^{\circ} \mathrm{C} / \pm 2,0 \% \\
538 \div 1050{ }^{\circ} \mathrm{C} / \pm 3,5 \%\end{array}$ & $0,1^{\circ} \mathrm{C}$ \\
\hline \multirow{2}{*}{$\begin{array}{l}\text { Multimeter } \\
\text { with thermocouple }\end{array}$} & Metex M-4660A & $-40 \div 1200^{\circ} \mathrm{C}$ & $\pm 3,5 \%$ & $0,1^{\circ} \mathrm{C}$ \\
\hline & Termopara typ $\mathrm{K}$ & $-40 \div 1200^{\circ} \mathrm{C}$ & $\begin{array}{c}-40 \div 333^{\circ} \mathrm{C} / \pm 2,5 \% \\
-333 \div 1200^{\circ} \mathrm{C} / \pm 0,0075^{\star} \mathrm{T} \%\end{array}$ & $\left(41 \mu \mathrm{V} /{ }^{\circ} \mathrm{C}\right)$ \\
\hline
\end{tabular}

Table II. Characteristics of filler wire for arc surfacing

\begin{tabular}{|c|c|c|c|c|c|c|c|c|c|}
\hline \multirow{2}{*}{ Material } & \multirow{2}{*}{$\begin{array}{c}\text { Diameter } \\
\text { of the electrode } \\
\text { wire }[\mathrm{mm}]\end{array}$} & \multicolumn{6}{|c|}{ Chemical composition [\%] } & \multirow{2}{*}{$\begin{array}{c}\mathrm{YS} \\
{\left[\mathrm{N} / \mathrm{mm}^{2}\right]}\end{array}$} & \multirow{2}{*}{$\begin{array}{c}\text { UTS } \\
{\left[\mathrm{N} / \mathrm{mm}^{2}\right]}\end{array}$} \\
\hline & & C & $\mathrm{Si}$ & $\mathrm{Mn}$ & $\mathrm{Cr}$ & $\mathrm{Ni}$ & Mo & & \\
\hline G3Si1 & 0,8 & 0,11 & 0,85 & 1,4 & - & - & - & 470 & 560 \\
\hline 316LSi & 0,8 & $<0,03$ & 0,80 & 1,8 & 19 & 12 & 2,7 & 440 & 620 \\
\hline
\end{tabular}


Table III. Arc surfacing parameters

\begin{tabular}{|c|c|c|c|c|c|}
\hline Material & $\begin{array}{c}\text { Surfacing current } \\
\text { intensity [A] }\end{array}$ & $\begin{array}{c}\text { Initial surfacing } \\
\text { current intensity [A] }\end{array}$ & Transition time [s] & Arc voltage [V] & $\begin{array}{c}\text { Electrode wire feeding } \\
\text { speed [m/min] }\end{array}$ \\
\hline G3Si1 & 80 & 85 & 2 & 12,3 & 5,4 \\
\hline $316 \mathrm{LSi}$ & 75 & 80 & 2 & 13,3 & 6,8 \\
\hline
\end{tabular}

Measurements of geometric dimensions of 3D models were carried out using an electronic caliper $(\mathrm{dz}=0.02 \mathrm{~mm})$. Samples for metallographic examinations were prepared in a standard manner. Metallographic examinations were digested with a $5 \%$ Nital solution (3D-G3Si1 model) and Mi16Fe reagent (3D-316LSi model). The structures were observed on Nikon Eclipse MA200 and Olympus SZX9 microscopes, using 5 to 250 magnification. HV hardness measurements were made along the axis of the padding weld using Leitz durometer, applying a load of $500 \mathrm{~g}$.

\section{Ways of cooling the 3D models}

The basic problems occurring during 3D printing with the use of MIG/MAG methods is to ensure a quick heat removal without damaging the model being created. Uninterrupted surfacing of subsequent layers causes the introduction of too much heat, which results, among others, in significant distortions and uneven growth of the model. This is the main reason for the difficulty in maintaining the right geometry of 3D models. The previously used, self-cooling between layers (padding welds) to a certain temperature caused long breaks in the process, significantly extending the time of the 3D model and making the process ineffective.

There are many factors (parameters) which influence the duration of the process of creating a 3D model by MIG/ MAG surfacing. The most important ones are: the type of surfaced material, the parameters of the surfacing (linear energy of the surfacing), the type of shielding gas used, the geometry and dimensions of the 3D model. The choice of material is determined by the specific application, as well as geometry and dimensions. Increasing the linear energy by increasing the value of the welding current causes, in addition to the higher melting efficiency, excessive heating of the $3 \mathrm{D}$ model and problems related to heat removal. The type of shielding gas influences i.e. the shape of padding weld and depth of penetration.

One way to shorten the duration of the process is to increase the surfacing speed. However, it turns out that relatively small changes in speed cause problems with maintaining the geometry of a thin-walled 3D model, and its further increase results in a lack of process stability and difficulties in obtaining the correct penetration.

Another way is to increase the permissible interlayer temperature, and thus shorten the cooling time. However, it should be remembered that it is conditioned by the type of the surfacing material. The adoption of its incorrect value may result in adverse changes in the structure of padding weld (3D model).

Further shortening of the surfacing time may consist of forced cooling of the model between the application of individual layers (padding welds) until a given temperature is obtained. This method seems to be the most advantageous in terms of technology, economy and application. However, it poses a risk of exceeding the critical cooling rate for the surfaced material, which may result in unfavorable structures, brittleness and tendency to crack.
Finally, two methods of shortening the process time, i.e. increasing the interlayer temperature and the use of various forced cooling methods, were used in the research.

\section{Procedure of making 3D models of thin walls}

Before surfacing each base plate was mechanically cleaned and then degreased. The base plates were fixed in the device (Fig. 2) by means of bolted strips (3), thus ensuring an even pressure and stiffness. In figure 2 , in addition to the wall model (4), the thermocouple's cable shield (5), thermocouple (2) and pyrometer's measuring place (1) are visible.

The procedure of making the 3D models included:

- surfacing successively eight buffer layers (undercoats) in order to reduce the influence of undercoats and the tooling base on heat absorption from the created 3D model;

- surfacing of successive layers with simultaneous temperature measurement by means of a pyrometer and thermocouple; the total number of layers was from 18 to 30 ;

- temperature measurement using a thermocouple in a blind hole drilled in the eighth layer in the middle of its length;

- temperature measurement by means of a pyrometer aimed at the face of the current layer in the middle of its length; the pyrometer's lens was located at a distance of $350 \mathrm{~mm}$, with the optical axis deflected by about $30^{\circ}$ from the vertical.

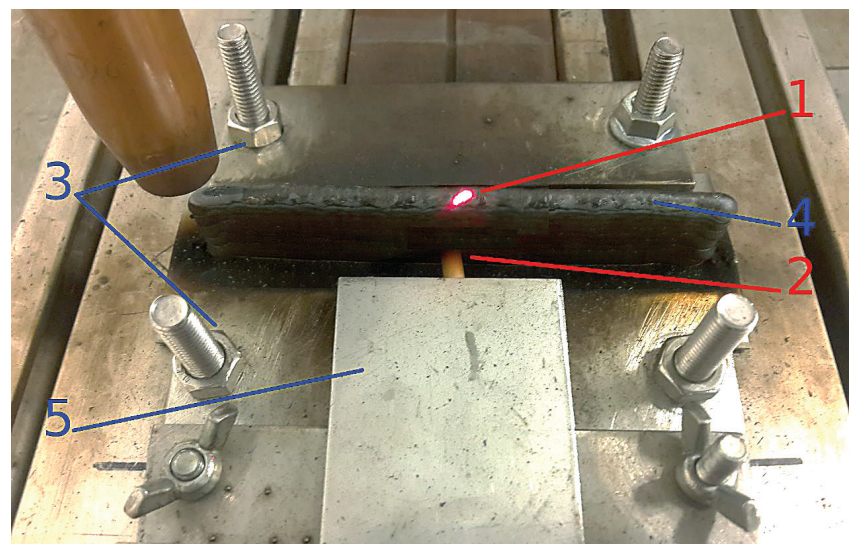

Fig. 2. Fastening of base plate (description in the text)

In the first stage of the tests, three inter-layer temperatures were tested: 50,100 and $150{ }^{\circ} \mathrm{C}$. The cooling to these temperatures took place in an intrinsic way. After reaching the given temperature the surfacing process was continued. In the second stage of the research, a constant temperature of $100{ }^{\circ} \mathrm{C}$ was adopted and three ways of forced cooling of the lateral surface of the 3D model of the wall were applied:

- by means of a copper plate, applied after each made layer to the side surface, on the opposite side in relation to the thermocouple's mounting,

- by forced air circulation parallel to the side walls of the 3D model (120 mm fan average, flow capacity approx. $230 \mathrm{~m}^{3} / \mathrm{h}$ ), 
- using compressed air obtained from the ABAC B3800B/ 150 CT3 oil compressor (the air stream was directed by means of a gun with a nozzle diameter of $1.5 \mathrm{~mm}$ tangentially to the side wall of the 3D model, located on the opposite side in relation to the thermocouple mounting; the gun was making oscillatory movements from the face to the base of the model).

The length of the padding welds forming the wall (Fig. 3) was approx. $115 \mathrm{~mm}$.

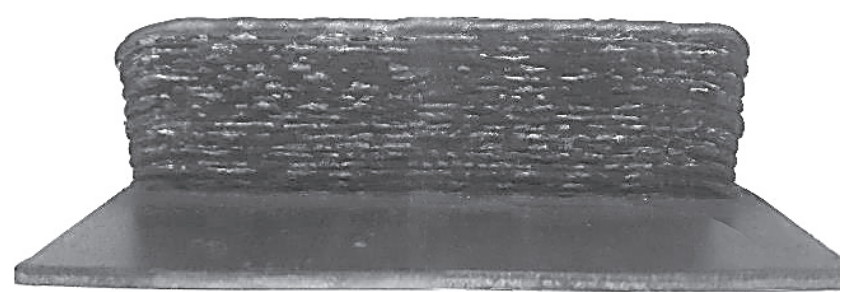

Fig. 3. 3D-G3Si1 model

\section{Research results}

As part of the study of 3D models of thin walls, real-time temperature was recorded, and after completion of the surfacing process, measurements of geometric dimensions, basic metallographic tests and hardness measurements. The research provided a very extensive material for analysis. Below are selected, sample results.

Figure 4 presents graphs showing temperature changes during the process. The curve (1) shows the temperature recorded using a stationary thermocouple, while (2) the temperature measured by the pyrometer on the face of the current layer. Additionally, lines (3) showing the periods of glow of the welding arc were applied to the waveforms. The following sequences shown in Figure 4 include:

a) 3D-G3Si1 model - self-cooled up to $50{ }^{\circ} \mathrm{C}$, number of layers: 8 (undercoat) +10 ;

b) $3 \mathrm{D}-316 \mathrm{LSi}$ model - self-cooled up to $50^{\circ} \mathrm{C}$, number of layers: 8 (undercoat) +10 ;

c) 3D-G3Si1 model - cooled with compressed air up to 100 ${ }^{\circ} \mathrm{C}$, number of layers: 8 (undercoat) +10 ;

d) 3D-316LSi model - cooled with compressed air up to 100 ${ }^{\circ} \mathrm{C}$, number of layers: 8 (undercoat) +10 .

Measurements of geometrical dimensions showed an average wall width in the range: $4.74 \div 5.34 \mathrm{~mm}$ for G3Si 1 models and $4.47 \div 5.84 \mathrm{~mm}$ for $316 \mathrm{LSi}$ models. Based on measurements of 3D model height and number of layers, the average thickness increase per layer was specified: $1.57 \div 1.76 \mathrm{~mm}$ for G3Si1 models and 1.79 $\div 2.17 \mathrm{~mm}$ for $316 \mathrm{LSi}$ models.

Figure 5 shows macrostructure cross-sections of selected 3D models made of $316 \mathrm{LSi}$ : with self-cooling up to $50^{\circ} \mathrm{C}$ (a) and with forced cooling to $100^{\circ} \mathrm{C}$ by means of a fan (b). The characteristic layout of the individual layers forming the 3D model wall and their mutual penetration in the transition areas is clearly visible. No welding incompatibilities were found. The 3D models from the G3Si1 material had similar construction.

Figure 6 shows second to last and last microstructure in 3D models made of G3Si1 (a) and 316LSi (b), self-cooled up to $100{ }^{\circ} \mathrm{C}$. It can be noticed that for the model made of G3Si1 below the last layer there are structures resulting from automatic heat treatment caused by multilayer surfacing (multiple thermal cycle) and a significant reduction in grain size. In the case of the model made of $316 \mathrm{LSi}$, the features of the transcrystalline structure of individual layers a)

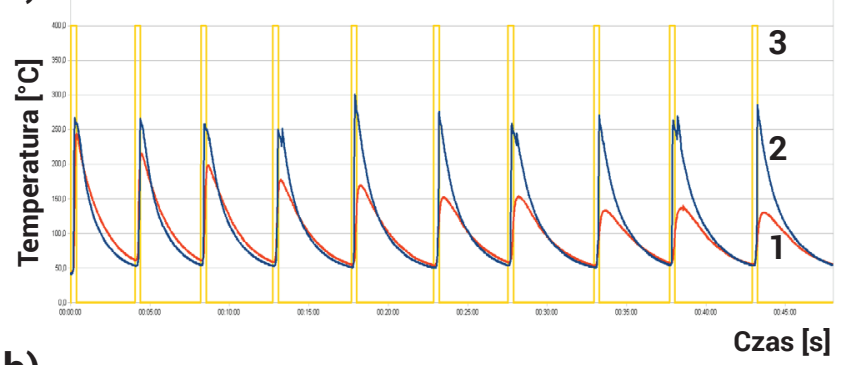

b)

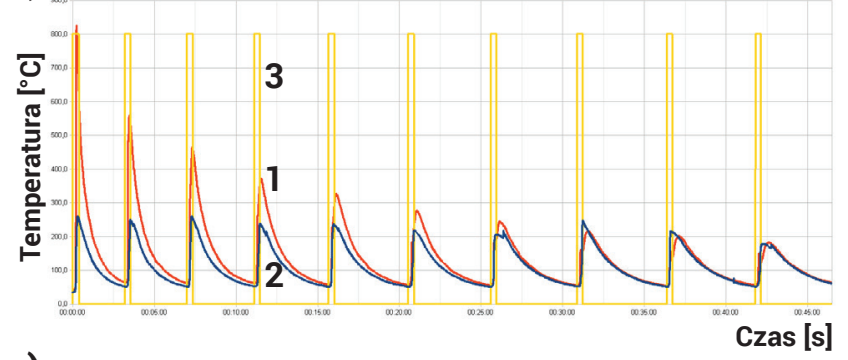

c)

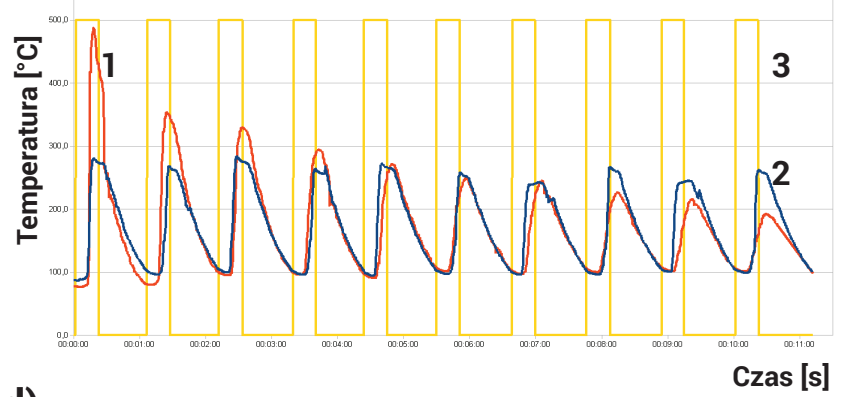

d)

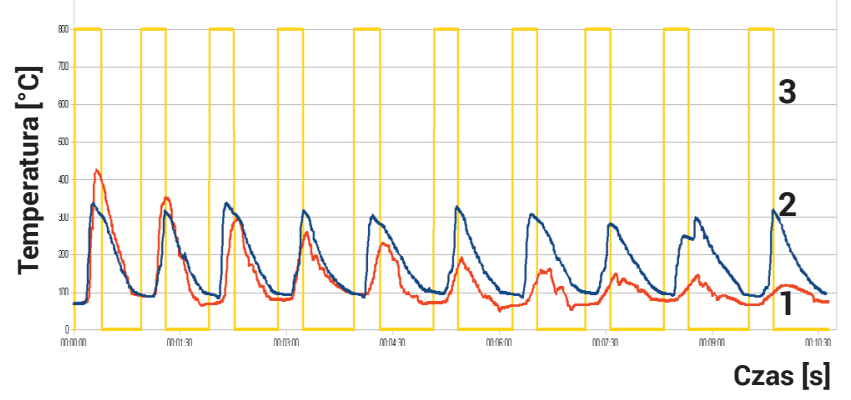

Fig. 4. Temperature changes during arc surfacing (description in the text)
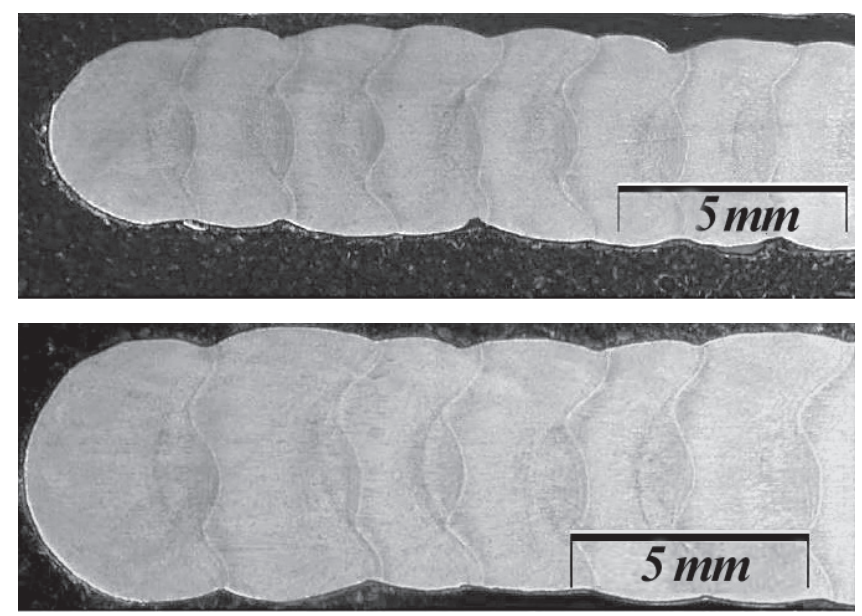

Fig. 5. Macrostructure of the cross-section of selected 3D-316LSi models 


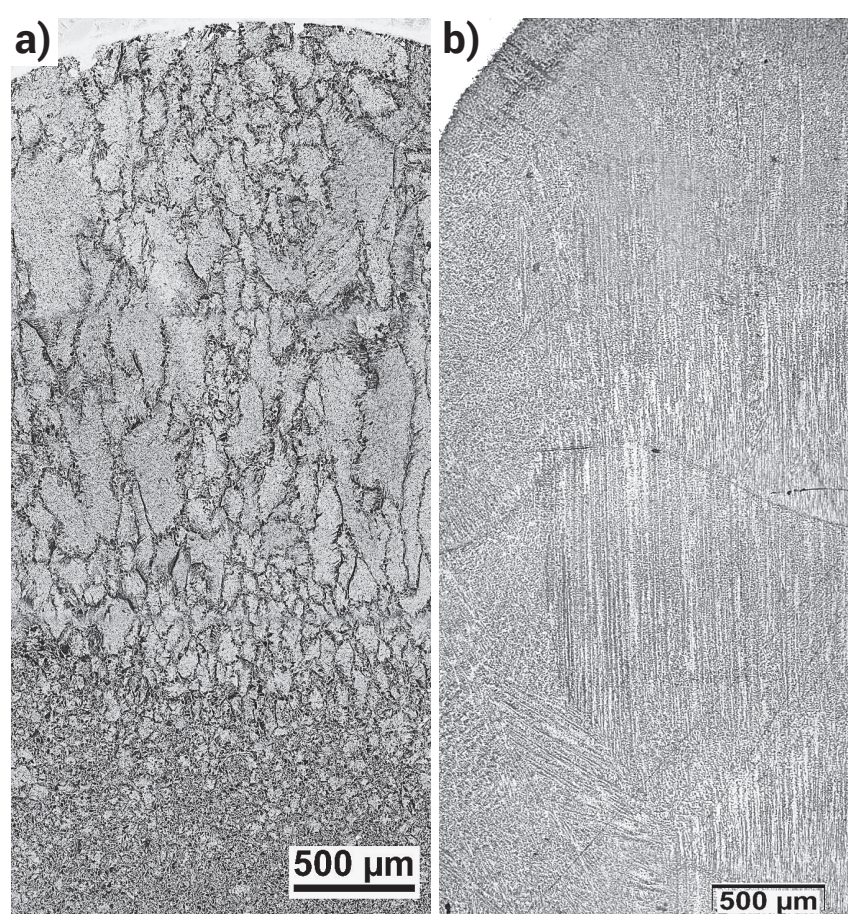

Fig. 6. Microstructure of the last layer in: 3D-G3Si1 (a) and 3D$-316 \mathrm{LSi}$ (b) models self-cooled to $100^{\circ} \mathrm{C}$

can be observed. In both cases, the last layer has a structure characteristic for welds made with a given species of an electrode wire.

The hardness of the face layer was measured at 176: $\div 213 \mathrm{HV}$ (3D-316LSi model) and 145 $\div 216 \mathrm{HV}$ (3D-G3Si1 model). A characteristic feature of the 316 LSi model is a slight increase in hardness with the increasing distance from the face of the last padding weld $(201 \div 226 \mathrm{HV}$ at a distance of $20 \mathrm{~mm}$ from the face). The precipitation of intermetallic phases may be the possible reason for the increase in hardness. For the 3D-G3Si1 model an inverse tendency was observed $(151 \div 169 \mathrm{HV})$.

\section{Analysis of the results}

On the basis of thermal cycling diagrams, the durations of the production process of individual 3D models were determined. In addition, the total cooling time, the cooling rate of the first and tenth layers and the value of the welding arc's glow coefficient were determined. The results of calculations are presented in Table IV.

Detailed results have shown, in line with the expectations and observation of the research that the shortest time of implementation of the 3D model was obtained with the use of compressed air cooling. This method allowed to achieve the highest values of the welding arc's glow coefficient (above $30 \%$ ) and significant reduction of the total cooling time (for the same interlayer temperature of $100{ }^{\circ} \mathrm{C}$ ). At the same time, the manual operation of the blow head is the least stable operation. Due to the technological break for the time of cooling, the same robot could manipulate the blow head in accordance with an individual program, adapted to the geometry of the 3D object being created.

The lowest effective was cooling down to the lowest interlayer temperature of $50{ }^{\circ} \mathrm{C}$. The tests and previous experience did not confirm the need to cool to such a low temperature.

The almost identical result achieved for cooling forced by a fan (up to $100^{\circ} \mathrm{C}$ ) and self-cooling to an interlayer temperature of $150^{\circ} \mathrm{C}$ turned out to be a surprise.

Table IV. List of quantities characterizing methods of the shortening process time

\begin{tabular}{|c|c|c|c|c|c|c|c|}
\hline Material & Cooling method & tc $[s]$ & $\operatorname{tc} 1[s]$ & tc10 [s] & $\operatorname{vc1}\left[{ }^{\circ} \mathrm{C} / \mathrm{s}\right]$ & $\mathrm{vc10}\left[{ }^{\circ} \mathrm{C} / \mathrm{s}\right]$ & Wj [\%] \\
\hline \multirow{6}{*}{ G3Si1 } & Self-cooled: $50^{\circ} \mathrm{C}$ & 2824 & 183 & 396 & 9,56 & 4,42 & 7,44 \\
\hline & Self-cooled: $100^{\circ} \mathrm{C}$ & 1332 & 56 & 137 & 30,36 & 12,41 & 15,77 \\
\hline & Self-cooled: $150^{\circ} \mathrm{C}$ & 1115 & 54 & 105 & 30,56 & 15,71 & 18,83 \\
\hline & Forced: copper plate $100^{\circ} \mathrm{C}$ & 1263 & 84 & 122 & 20,24 & 13,93 & 16,63 \\
\hline & Forced: fan $100^{\circ} \mathrm{C}$ & 1071 & 72 & 109 & 23,61 & 15,60 & 19,61 \\
\hline & Forced: compressed air $100^{\circ} \mathrm{C}$ & 639 & 37 & 45 & 45,95 & 37,78 & 32,86 \\
\hline \multirow{6}{*}{ 316LSi } & Self-cooled: $50^{\circ} \mathrm{C}$ & 2889 & 221 & 312 & 7,92 & 5,61 & 7,27 \\
\hline & Self-cooled: $100^{\circ} \mathrm{C}$ & 1677 & 147 & 150 & 11,56 & 11,33 & 12,52 \\
\hline & Self-cooled: $150^{\circ} \mathrm{C}$ & 1116 & 78 & 103 & 21,15 & 16,02 & 18,82 \\
\hline & Forced: copper plate $100^{\circ} \mathrm{C}$ & 1656 & 144 & 143 & 11,81 & 11,89 & 12,68 \\
\hline & Forced: fan $100^{\circ} \mathrm{C}$ & 1147 & 85 & 85 & 20,00 & 20,00 & 18,31 \\
\hline & Forced: compressed air $100^{\circ} \mathrm{C}$ & 662 & 54 & 40 & 31,48 & 42,50 & 31,72 \\
\hline \multicolumn{8}{|c|}{$\begin{array}{l}\text { tc }- \text { total cooling time } \\
\text { tc } 1 \text { - cooling time of the first test layer } \\
\text { tc10 - cooling time of the tenth test layer } \\
\text { vc } 1 \text { - cooling rate of the first test layer } \\
\text { vc10 - cooling rate of the tenth test layer } \\
\text { vc - welding arc's glow coefficient }\end{array}$} \\
\hline
\end{tabular}




\section{Summary}

The tests have shown the possibility of effective shortening the time of the 3D printing process by MIG/MAG surfacing. On the basis of preliminary metallographic tests, no unfavorable structures in the padding welds were found. This is probably due to the occurrence of the automatic heat treatment of previously applied layers in the multi-layer surfacing process. There were also no significant welding imperfections. The above note does not refer to the observed waviness of the side walls, but currently there are no guidelines, let alone the normative quality recommendations for 3D printing by arc surfacing.

The conducted research shows that the development of the 3D printing process using the MIG / MAG method of each new product requires, to a large extent, the use of an individual approach. Precise prediction of the properties of such created objects requires further, detailed research.

\section{References}

[1] P. Siemiński, G. Budzik, Techniki przyrostowe. Druk 3D. Drukarki 3D, Oficyna Wydawnicza Politechniki Warszawskiej, Warszawa (2015)

[2] P.M. Dickens, R. Cobb, I. Gibson, M.S. Pridham, Rapid Prototyping Using 3D Welding, Journal of Design and Manufacturing (1993), 3.

[3] Z. Wang; T.A. Palmer; A.M. Beese, Effect of processing parameters on microstructure and tensile properties of austenitic stainless steel $304 \mathrm{~L}$ made by directed energy deposition additive manufacturing, Acta Materialia (2016), 110, 226-235.

[4] T.E. Abioye, A. Medrano-Telllez, P.K. Farayibi, P.K. Oke, Laser metal deposition of multi-track walls of 308LSi stainless steel, Materials and Manufacturing Processes (2017), vol. 32 (14), 1660-1666, DOI: 10.1080/10426914. 2017.1292034

[5] P. Cegielski, Nowe obszary zastosowania napawania łukowego MIG/ MAG, Welding Technology Review (2016), vol. 88 (6), 48-49
[6] P. Cegielski, A. Skublewska, P. Gawroński, M. Ostrysz, M. Dylewski, M. Gajowniczek, Zastosowanie napawania łukowego MIG/MAG do drukowania 3D, Spajanie (2016), 2, 22-26.

[7] P. Cegielski, M. Ostrysz, W. Łacisz, M. Panas, P. Kowalski, Nowe prace nad wykorzystaniem napawania łukowego MIG/MAG do drukowania 3D,Welding Technology Review (2018) vol. 89 (1), 43-47.

[8] S. Selvi, A. Vishvaksenan, E. Rajasekar, Cold metal transfer (CMT) technology - An overview, Defence Technology (2018), vol. 14 (1), 28-44.

[9] W. Łacisz, Intensyfikacja wytwarzania cienkich ścian na drodze wielowarstwowego napawania łukowego. Praca dyplomowa inżynierska, Politechnika Warszawska, Warszawa (2018).

(C) 2019 by the authors. Submitted for possible open access publication under the terms and conditions of the Creative Commons Attribution (CC BY) license (http://creativecommons.org/licenses/by/4.0/). 